DOI: $10.15193 /$ zntj/2017/111/192

\author{
MAŁGORZATA WRZOSEK, BEATA BILSKA, \\ DANUTA KOŁOŻYN-KRAJEWSKA, KAROL KRAJEWSKI
}

\title{
ZASTOSOWANIE ANALIZY RYZYKA DO OPRACOWANIA INNOWACYJNEGO SYSTEMU OGRANICZANIA STRAT I MARNOWANIA ŻYWNOŚCI W HANDLU DETALICZNYM (SYSTEM MOST)
}

\begin{abstract}
Streszczenie
Redystrybucja żywności na cele społeczne może stanowić jeden z kluczowych i pożądanych sposobów ograniczania strat żywności. Rozwiązanie umożliwia uzyskanie wielopłaszczyznowych korzyści, z których najważniejszą jest poprawa dostępu do żywności osób o niskim dochodzie. Działania takie są praktykowane w krajach europejskich, np. w Wielkiej Brytanii i w Hiszpanii, gdzie nadwyżki żywności znajdujące się w dystrybucji są przekazywane organizacjom społecznym.

Celem pracy było zastosowanie metody analizy ryzyka do opracowania innowacyjnego systemu ograniczania strat i marnowania żywności w handlu detalicznym (Model Ograniczenia Strat Żywności z Korzyścią dla Społeczeństwa - akronim MOST), rozumianego jako ogół działań i przedsięwzięć podejmowanych przez Przedsiębiorcę $\mathrm{w}$ porozumieniu z Organizacją ds. redystrybucji żywności. W pracy przedstawiono podsumowanie badań obejmujących opracowanie sytemu umożliwiającego identyfikację strat żywności powstających w handlu detalicznym oraz zagospodarowanie żywności zdatnej do spożycia na cele społeczne. Zaproponowany system MOST został opracowany na podstawie uniwersalnej dla wielu branż metody analizy ryzyka oraz funkcjonującego i obligatoryjnego w przedsiębiorstwach branży spożywczej systemu HACCP, dzięki czemu można go włączyć w działalność firmy bez ponoszenia dodatkowych nakładów finansowych. Opracowany system obejmuje charakterystyczne dla metody analizy ryzyka etapy, takie jak: ocena ryzyka, zarządzanie ryzykiem oraz jego komunikacja. Szczegółowej analizie poddawana była identyfikacja czynników oraz przyczyn wystąpienia strat żywności, na podstawie których wyznacza są Potencjalne Punkty Odzysku, mogące stać się po walidacji Punktami Odzysku.
\end{abstract}

Słowa kluczowe: analiza ryzyka, ocena ryzyka strat żywności, zarządzanie stratami żywności w handlu, system MOST, straty żywności w handlu

Mgr inż. M. Wrzosek, dr inż. B. Bilska, prof. dr hab. D. Kolożyn-Krajewska, Katedra Technologii Gastronomicznej i Higieny Żywności, Wydz. Nauk o Żywieniu Człowieka i Konsumpcji, Szkoła Główna Gospodarstwa Wiejskiego w Warszawie, ul. Nowoursynowska 159C, 02-776 Warszawa, dr inż. K Krajewski, Instytut Nauk Technicznych, Państwowa Wyższa Szkoła Wschodnioeuropejska w Przemyślu, ul. Żotnierzy I Armii Wojska Polskiego 1 E, 37-700 Przemyśl. Kontakt: wrzosekmalgorzata@wp.pl 


\section{Wprowadzenie}

\section{Problem strat i marnotrawstwa żywności}

Pod pojęciem „bezpieczeństwo żywnościowe” rozumie się nieprzerwany i swobodny dostęp fizyczny, jak również ekonomiczny do żywności, który pozwala na zaspokojenie potrzeb żywnościowych i gwarantuje prawidłowy rozwój oraz zachowanie sprawności fizycznej i intelektualnej ludzi [4]. Mimo to jednym z głównych problemów XXI wieku jest zróżnicowany poziom życia ludności, co warunkuje możliwość ilościowego, jak i jakościowego dostępu do artykułów żywnościowych. Modelem najbardziej pożądanym jest równowaga pomiędzy popytem a podażą żywności, ponieważ odchylenia od tego stanu prowadzą do diagonalnych względem siebie, ale niepożądanych zjawisk (otyłość, cukrzyca, niedożywienie, głód). W krajach rozwiniętych dominuje model nadkonsumpcji, zaś w krajach rozwijających się - problem niedożywienia i głodu.

Modele te ulegają przekształceniom na skutek globalnych zmian gospodarczych i społecznych, co stymulowane jest dodatkowo przez intensyfikację rolnictwa, technicyzację (nowe technologie utrwalania i przechowywania produktów), dużą skalę produkcji w przetwórstwie żywności, stosowanie przedłużania okresu przydatności do spożycia, wydłużenie kanałów dystrybucji, pojawienie się dużych sieci detalistów. Zjawiska te prowadzą do konieczności zarządzania coraz większymi ilościami surowców i produktów w łańcuchu żywnościowym, co w konsekwencji może prowadzić do strat i marnotrawstwa żywności, spowodowanych brakiem równowagi w łańcuchu [11].

Zjawisko strat i marnotrawstwa żywności zachodzi na wszystkich etapach łańcucha żywnościowego „od pola do stołu”, poczynając od produkcji pierwotnej, przetwórstwa, handlu, gastronomii, dystrybucji, kończąc na gospodarstwach domowych. Struktura zjawiska w 27 krajach Unii Europejskiej wygląda następująco: gospodarstwa domowe (42\%), produkcja (39 \%), usługi żywieniowe (14\%) i sprzedaż detaliczna i hurtowa (5\%) [12]. Za straty żywności uznaje się zmniejszenie ogólnej masy jadalnych części żywności, których pierwotne przeznaczenie związane było z konsumpcją przez ludzi. Ujmuje ona ilość żywności, która początkowo była wyprodukowana na cele konsumpcyjne, jednak ostatecznie uległa naturalnym ubytkom masy (np. wysychaniu), zepsuciu lub została wykorzystana w innym celu (np. do produkcji biopaliwa, kompostu, pasz itd.) [2]. Do strat nie wlicza się natomiast części niejadalnych (np. kości, łupin itd.) oraz surowców i produktów pierwotnie wytworzonych na cele niekonsumpcyjne (pasz, biokomponentów, bioenergii, surowców opakowalniczvch itp.) [4]. Zgodnie z nomenklaturą przyjętą przez Grupę Roboczą ds. Racjonalnego Wykorzystania Żywności przy Federacji Polskich Banków Żywności straty to zmniejszenie masy jadalnej żywności wynikające z niegospodarności, błędów i nieprawidłowości 
w przebiegu procesów, np. w produkcji rolniczej, podczas zbiorów, w przetwórstwie, transporcie czy w handlu. Natomiast termin „marnotrawstwo żywności” odnosi się do nieracjonalnych procesów gospodarowania zachodzących w obszarze gastronomii i gospodarstw domowych [19].

Jak wynika z raportu Organizacji Narodów Zjednoczonych do spraw Wyżywienia i Rolnictwa, rocznie na świecie marnuje się ok. 1/3 ogółu produkowanej żywności, co w ujęciu masowym wynosi ok. 1,3 miliarda ton żywności. Dla porównania w samej Europie marnuje się ok. $89 \mathrm{mln}$ ton żywności (ok. $179 \mathrm{~kg}$ żywności rocznie/mieszkańca) odpowiadającej $20 \div 30 \%$ ogólnej masy zakupionych produktów spożywczych, z czego prawie $67 \%$ nadawałaby się jeszcze do konsumpcji. [2]. Za największą masę marnowanej żywności odpowiedzialni są kolejno: Holendrzy (579 kg/os./rok), Belgowie (399 kg/os./rok) oraz Cypryjczycy (334 kg/os./rok), natomiast wśród krajów marnujących najmniej wyróżnia się: Grecję (44 kg/os./rok), Maltę (62 kg/os./rok) i Czechy (71 kg/os./rok) [1, 2]. Szacuje się, że w Polsce marnuje się ok. $235 \mathrm{~kg} / \mathrm{os}$./rok. Natomiast w strukturze marnowanych produktów żywnościowych na świecie dominują: warzywa oraz owoce (27\%), napoje (17\%), pieczywo (11\%), dania gotowe (10\%), nabiał (10\%) i mięso (7\%) [16].

\section{Analiza ryzyka - teoria}

Pojęcie „ryzyko” jest powszechnie używane w wielu dziedzinach naukowych, życiu codziennym, jak również w ujęciu biznesowym. W wielu przypadkach jego definicja jest zupełnie odmienna, a charakter ryzyka wieloznaczeniowy. Nawet w obrębie jednej dyscypliny wśród autorów można zaobserwować różnice w jego definiowaniu. Etymologia słowa „ryzyko” wywodzi się ze starożytnej greki, gdzie riza oznaczało rafę i związany z nią stan wysokiego zagrożenia i niepewności załogi żeglarskiej [15].

Powszechnie „ryzyko” rozumiane jest jako prawdopodobieństwo zaistnienia negatywnych skutków w następstwie losowego wystąpienia określonego zagrożenia (czynniki, procesy, działania, zdarzenia losowe, właściwości rzeczy i/lub osób, zachodzące zmiany itp.). Natomiast główną determinantą ryzyka jest sposób rozumienia lub też rodzaj zagrożenia tworzącego charakter i zakres obszarowy, którego owe ryzyko dotyczy [9].

Sama idea zarządzania ryzykiem powstała na przełomie lat czterdziestych i pięćdziesiątych XX wieku w branży ubezpieczeniowej, potem finansowej oraz w innych obszarach, takich jak: bezpieczeństwo i higiena pracy, bezpieczeństwo informacji, ciągłość działania, ekologia i inne [10]. Bez względu jednak na rodzaj zagrożenia czy też branżę, której dotyczy dane ryzyko, uniwersalna zdaje się być koncepcja zarządzania ryzykiem, która ma na celu zminimalizowanie jego negatywnych skutków. Podstawą zarządzania ryzykiem jest systematyczne, terminowe oraz ustrukturyzowane podejmowanie decyzji w warunkach niepewności, które polega na identyfikacji moż- 
liwych zagrożeń oraz stosowaniu działań zapobiegawczych i naprawczych. Konieczna do prawidłowego zabezpieczenia jest elastyczność prowadzonych działań oraz aktualizacja względem zachodzących zmian w strukturach i/lub procesach organizacji, jak również względem rozszerzających się horyzontów wiedzy (np. wiedza na temat nowych rodzajów ryzyka, zagrożeń) [14].

Dla przykładu w branży żywnościowej ryzyko związane z wystąpieniem zagrożenia biologicznego (w tym mikrobiologicznego), chemicznego czy też fizycznego może wpływać na brak możliwości zagwarantowania bezpieczeństwa zdrowotnego żywności, a tym samym utrzymania określonego stanu zdrowotnego społeczeństwa [7]. Na mocy Rozporządzenia (WE) nr 178/2002 Parlamentu Europejskiego i Rady z 28 stycznia 2002 r., ustanawiającego ogólne zasady i wymagania prawa żywnościowego, powołującego Europejski Urząd ds. Bezpieczeństwa Żywności oraz ustanawiającego procedury z zakresu bezpieczeństwa żywności, producenci „łańcucha żywnościowego” są zobowiązani do przestrzegania zasad obligatoryjnych systemów GHP, GMP oraz HACCP w celu eliminacji zagrożeń i tym samym ochrony zdrowia i życia człowieka. Na podstawie rozporządzenia ryzyko zostało zdefiniowane jako ,niebezpieczeństwo zaistnienia negatywnych skutków dla zdrowia oraz dotkliwość takich skutków w następstwie zagrożenia”, natomiast metodą ułatwiającą proces zarządzania bezpieczeństwem żywności jest ich analiza. Według Rozporządzenia nr 178/2002 z dnia 28 stycznia 2002 r. analiza ryzyka gwarantuje zminimalizowanie występowania zagrożeń na drodze identyfikacji oraz charakterystyki prawdopodobnych zagrożeń, zaplanowanie działań monitorujących ich wystąpienie oraz działań naprawczych podejmowanych w chwili ich wykrycia. Kooperacja składowych, takich jak: analiza zagrożeń, poziom wiedzy oraz potwierdzające ją badania naukowe dotyczące problemów zdrowia publicznego mają za wspólny cel zagwarantowanie bezpieczeństwa żywności (ang. Food Safety Objective - FSO) oraz odpowiedniego poziomu ochrony życia lub zdrowia ludzi (ang. Appropriate Level of Protection - ALOP). Czynnością operacyjną, która realizuje te właśnie cele, jest ograniczenie lub całkowita eliminacja wystąpienia czynników, które mogą wpływać na zagwarantowanie bezpieczeństwa zdrowotnego żywności [13].

Zgodnie z Rozporządzeniem Parlamentu Europejskiego nr 178/2002 na analizę ryzyka składają się trzy podstawowe elementy, jakimi są: ocena ryzyka (ang. risk assessment), zarządzanie ryzykiem (ang. risk management) i komunikacja ryzyka (ang. risk communication). Pierwszy z tych elementów powinien być przeprowadzony indywidualnie przez każde przedsiębiorstwo biorące udział w budowie łańcucha „od pola do stołu" i składa się z czterech etapów, o podbudowie naukowej, następujących po sobie:

1. Identyfikacja zagrożeń - ang. hazard identification - polega na określeniu potencjalnych zagrożeń (biologicznych, chemicznych i fizycznych) oraz ich wpływu na 
zdrowie ludzi. Podstawowym źródłem danych są np. badania epidemiologiczne, mikrobiologiczne, kliniczne.

2. Oszacowanie zagrożeń - ang. hazard characterization (nazywane inaczej charakterystyką niebezpieczeństwa) - polega na przeprowadzeniu analizy jakościowej oraz ilościowej. Analiza jakościowa określa istotność oraz prawdopodobieństwo wystąpienia zagrożenia. W przypadku analizy ilościowej wyznaczana jest wielkość dawki spożywanego produktu.

3. Oszacowanie ryzyka - ang. exposure assessment (nazywane również oszacowaniem narażenia lub oceną ekspozycji) - polega na określeniu wielkości zagrożeń mikrobiologicznych oraz chemicznych występujących w żywności, dzięki czemu można ustalić wielkość dawki pobrania tych czynników w danej grupie lub populacji.

4. Charakterystyka ryzyka - ang. risk characterization - polega na zebraniu wszystkich wcześniejszych informacji oraz określeniu na tej podstawie możliwych do wystąpienia niepożądanych dla danej grupy (populacji) skutków zdrowotnych [13]. Drugim filarem budującym analizę ryzyka jest zarządzanie ryzykiem rozumiane jako proces polegający na zbadaniu wspólnej polityki między zainteresowanymi stronami, która ujmować będzie ocenę ryzyka i innych prawnie uzasadnionych czynników i w razie potrzeby polegać będzie na wybraniu stosownych sposobów ich zapobiegania i kontroli. Na zarządzanie ryzykiem składają się cztery elementy: ocena ryzyka, ocena poszczególnych opcji, wdrożenie wybranej opcji, monitorowanie i przeglądy. Jest to obszar, którego obsługa jest prowadzona przez instytucje państwowe zarządzające ryzykiem. Ich zadaniem jest ograniczanie możliwości wystąpienia danego ryzyka [13].

Ostatnim elementem jest komunikacja ryzyka, która jest integralną częścią współoddziaływania ze wszystkimi stronami biorącymi udział w prowadzonej analizie ryzyka. Kluczową i najskuteczniejszą strategią w komunikacji ryzyka jest dialog, w który aktywnie zaangażowane są wszystkie zainteresowane strony:

a) przedsiębiorstwa zajmujące się produkcją, przetwórstwem oraz obrotem żywnością - oceniający ryzyko (odpowiedzialni za pierwszy etap analizy ryzyka - ocenę ryzyka),

b) instytucje rządowe zarządzające ryzykiem,

c) konsumenci (społeczeństwo),

d) przedsiębiorstwa żywnościowe i paszowe,

e) środowisko naukowe,

f) inne zainteresowane strony.

Celem pracy było zastosowanie metody analizy ryzyka do opracowania innowacyjnego systemu ograniczania strat i marnowania żywności w handlu detalicznym, rozumianego jako ogół działań i przedsięwzięć podejmowanych przez Przedsiębiorcę w porozumieniu z Organizacją ds. redystrybucji żywności. W publikacji omówiono 
podstawy i założenia teoretyczne, uporządkowanie oraz podsumowanie elementów systemu przedstawionych szczegółowo we wcześniejszych publikacjach autorów.

\section{Ustrukturyzowanie modelu zarządzania stratami żywności}

Struktura strat żywności przedstawiona przez FAO wskazuje że blisko 33 \% produktów uznanych za odpady nie nadaje się do dalszej konsumpcji, natomiast pozostałe 2/3 żywności mogłyby zostać skonsumowana (np. przekazane w tym celu do organizacji zajmujących się dalszą redystrybucją lub też wykorzystane jako surowiec do przygotowania posiłków w jadłodajniach) [2]. To może być podstawą do rozwoju idei ograniczania strat żywności poprzez wspieranie działań mających na celu jej dalsze zagospodarowanie na cele konsumpcyjne. Straty rozumiane jako zmniejszenie zysku przedsiębiorstwa są tematem powszechnym w świecie biznesu, natomiast w przypadku łańcucha żywnościowego problematyka dotycząca szacowania strat żywności i zarządzania nimi nadal jest tematem innowacyjnym, który wymaga wielopłaszczyznowych analiz i podejścia systemowego. Przykładem mogą być badania własne prowadzone w tym zakresie w Polsce $[5,8,17,18]$, w których podstawą do stworzenia programu ograniczania strat żywności ukierunkowanego na jej zagospodarowanie na cele społeczne była ocena ilościowa strat żywności oraz wskazanie konkretnych miejsc ich powstawania. Następnym zadaniem badawczym było wykorzystanie otrzymanych wyników do opracowania systemu zarządzenia wykrytymi nadwyżkami. Według przywołanych badań zaproponowany system powinien cechować się prostotą obsługi, możliwością zastosowania $\mathrm{w}$ różnych procesach oraz formatach przedsiębiorstw, jak również nie powinien generować dodatkowych nakładów finansowych.

Przełomem w pracach własnych na etapie tworzenia założeń teoretycznych było zastosowanie metody analizy ryzyka do opracowania systemu służącego do ograniczania strat żywności w Polsce (rys. 1, tab. 1). Opracowany system został nazwany MOST i zdefiniowany jako ogół działań i przedsięwzięć podejmowanych przez Przedsiębiorcę w porozumieniu z Organizacją ds. redystrybucji żywności, mających na celu doprowadzanie do ograniczania strat i marnowania żywności z korzyścią dla społeczeństwa. W celu ułatwienia aplikacji systemu w firmach została opracowana procedura MOST, która bazuje na etapach i zasadach obligatoryjnego systemu HACCP. Ideą opracowania procedury było ułatwienie współpracy i komunikacji pomiędzy przedsiębiorstwem chcącym przekazać żywność na cele społeczne a organizacją zajmującą się jej dalszą redystrybucją. Założono, że zaproponowanie zakresu odpowiedzialności oraz kroków, jakie należy podjąć, w dalszej perspektywie może skutkować większym zainteresowaniem firm, które nadwyżki żywnościowe chciałyby zagospodarować w sposób społecznie odpowiedzialny, tj. ukierunkowujący je na cele konsumpcyjne. Zaproponowany system ma zastosowanie praktyczne dzięki opracowanej dokumentacji, w tym planu MOST. 


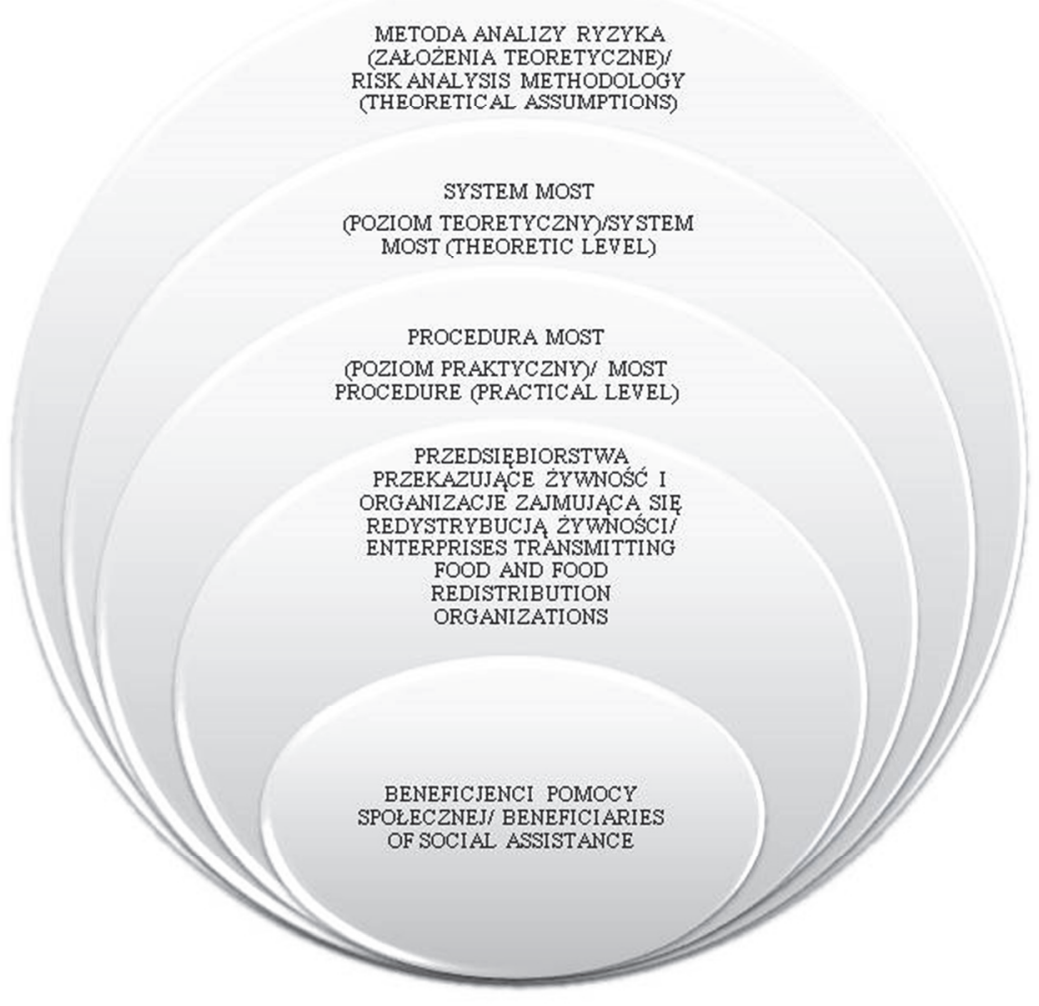

Rys. 1. Metoda analizy ryzyka w systemie MOST

Fig. 1. Risk analysis method in MOST system

Źródło / Source: Opracowanie własne / The authors' own study

\section{Ocena ryzyka (ang. risk assessment)}

Identyfikacja czynnika oraz określenie przyczyn i skutków jego wystapienia

Pierwszym elementem charakterystycznym dla metody analizy ryzyka jest ocena ryzyka (tab. 1). W badaniach własnych etap ten obejmował badania ankietowe w 117 obiektach handlowych zlokalizowanych na terenie województwa mazowieckiego i podkarpackiego, w których wykazano, że handel generuje straty na poziomie ok. $5,63 \%$. Natomiast za najczęstszą przyczynę ich powstawania wskazano przekroczenie terminu przydatności do spożycia oraz uszkodzenie mechaniczne opakowań jednostkowych. 
Tabela 1. Odniesienie metody analizy ryzyka według Codex Alimentarius do opracowanej analizy ryzyka strat żywności

Table 1. Risk analysis method acc. to Codex Alimentarius in relation to risk developed analysis of food losses

\begin{tabular}{|c|c|}
\hline $\begin{array}{c}\text { Analiza ryzyka według Codex } \\
\text { Alimentarius / Risk analysis } \\
\text { method acc. Codex Alimentarius }\end{array}$ & $\begin{array}{l}\text { Analiza ryzyka strat żywności } \\
\text { Risk analysis of food losses }\end{array}$ \\
\hline $\begin{array}{ll}\text { I. } & \text { Ocena ryzyka } \\
\text { Risk assessment } \\
\text { 1. } \\
\text { Identyfikacja zagrożeń } \\
\text { Identification of hazards } \\
\text { 2. Oszacowanie zagrożeń } \\
\text { Estimate of hazards } \\
\text { 3. Oszacowanie ryzyka } \\
\text { Risk estimation } \\
\text { 4. } \text { Charakterystyka ryzyka } \\
\text { Risk characterisation }\end{array}$ & $\begin{array}{l}\text { I. Ocena ryzyka } \\
\text { Risk assessment } \\
\text { 1. Identyfikacja czynnika (badania ankietowe w } 117 \text { obiektach handlo- } \\
\text { wych) / Identification of factor (surveys in } 117 \text { shopping facilities) } \\
\text { 2. Określenie przyczyny oraz skutku wystąpienia danego czynnika (mo- } \\
\text { dele przyczynowo-skutkowe według Ishikawy) / Determining cause } \\
\text { and effect leading to occurrence of factor (cause-effect models acc. to } \\
\text { Ishikawa) } \\
\text { 3. Analiza obniżenia jakości produktu } \\
\text { Analysis of decrease in product quality: } \\
\text { 3.1. Identyfikacja kategorii czynnika / Identification of factor catego- } \\
\text { ries } \\
\text { 3.2. Ocena istotności zagrożenia } \\
\text { Hazard significance assessment } \\
\text { 3.3. Wyznaczenie Potencjalnych Punktów Odzysku (PPO) } \\
\text { Determining Potential Recovery Points (PRP) }\end{array}$ \\
\hline $\begin{array}{l}\text { II. Zarządzanie ryzykiem } \\
\text { Risk management } \\
\text { 1. Ocena ryzyka } \\
\text { Risk assessment } \\
\text { 2. Ocena poszczególnych opcji } \\
\text { Evaluation of individual op- } \\
\text { tions } \\
\text { 3. Wdrożenie wybranej opcji } \\
\text { Implementing selected option } \\
\text { 4. Monitorowanie i przeglądy } \\
\text { Monitoring and Reviews }\end{array}$ & $\begin{array}{l}\text { II. Zarządzanie ryzykiem / Risk management } \\
\text { 1. Określenie limitów krytycznych umożliwiających odzysk produktu } \\
\text { Defining critical limits to enable recovery of product } \\
\text { 2. Zaplanowanie działan monitorujących dla danego PPO } \\
\text { Plan of monitoring activities for given PRP } \\
\text { 3. Walidacja PPO celem wyznaczenia Punktów Odzysku PO (metoda } \\
\text { FMEA-PO) / Validation of PRP in order to determine RPs (FMEA-PR } \\
\text { method) } \\
\text { 4. Zaplanowanie działań korygujących w celu przekazania produktu z } \\
\text { wyznaczonych PO / Planning corrective actions in order to transfer } \\
\text { the product from designated PRs } \\
\text { 5. Ocena Systemu MOST (Procedura audytu z check - listą) } \\
\text { Evaluation of MOST System (Audit procedure with checklist) }\end{array}$ \\
\hline $\begin{array}{l}\text { III. Komunikacja ryzyka } \\
\text { Risk communication } \\
\text { 1. Reklamacje, szkolenia, } \\
\text { audyty itd. } \\
\text { Complaints, training, audits, } \\
\text { etc. }\end{array}$ & $\begin{array}{l}\text { III. Komunikacja ryzyka / Risk communication } \\
\text { Współpraca zgodna z procedurą MOST pomiędzy: } \\
\text { Co-operation acc. to MOST system between: } \\
\text { a) Przedsiębiorstwem przekazującym żywność a Bankiem Żywności } \\
\text { Food donating enterprise and Food Bank } \\
\text { b) Bankiem Żywności a beneficjentami pomocy żywnościowej / Food } \\
\text { Bank and beneficiaries of food aid } \\
\text { c) Specjalistami Polskiego Towarzystwa Technologów Żywności (szko- } \\
\text { lenia z zakresu wdrażania MOST) a Bankami Żywności / Experts } \\
\text { from PTTŻ (MOST implementation training) and Food Bank } \\
\text { d) Specjalistami Polskiego Towarzystwa Technologów Żywności } \\
\text { (szkolenia z zakresu wdrażania MOST) a przedsiębiorstwami prze- } \\
\text { kazującymi żywność / Experts from PTTŻ (MOST implementation } \\
\text { training) and food donating enterprises }\end{array}$ \\
\hline
\end{tabular}

Źródło / Source: Opracowanie własne / The authors' own study 
Kolejnym etapem było przeprowadzenie analiz przyczynowo-skutkowych według modelu Ishikawy, dzięki którym określono szczegółowo przyczyny oraz skutki wystąpienia danego czynnika, który może doprowadzić do strat żywności na etapie handlu. Badania te zostały przedstawione w publikacjach autorów metody MOST $[5,8,17$, $18]$.

Analiza obniżenia jakości produktu - identyfikacja kategorii czynnika, ocena istotności zagrożenia oraz wyznaczenie Potencjalnych Punktów Odzysku (PPO)

Modele opracowane według Ishikawy posłużyły do opracowania własnej, autorskiej metody - analizy obniżenia jakości produktu, będącej procesem zbierania i oceniania informacji o możliwości wystąpienia zagrożeń mogących doprowadzić do ograniczenia lub braku możliwości wykorzystania produktu na cele konsumpcyjne. Analiza ta stanowiła element procedury MOST i była przeprowadzana dla każdego etapu/procesu występującego w handlu żywnością (etap przyjęcia towaru, magazynowania, ekspozycji, transportu wewnętrznego). W ramach analizy określeniu podlegał czynnik warunkujący obniżenie jakości towaru oraz przyczyna i skutek jego wystąpienia. Za czynnik przyjęto działanie lub proces, który może doprowadzić do obniżenia jakości produktu i tym samym doprowadzić do braku możliwości jego wykorzystania na cele konsumpcyjne. Przyczyna to powód wystąpienia czynnika obniżającego jakość produktu, zaś skutek to efekt jego wystąpienia (tab. 2).

W dalszym rozważaniu opracowana metoda analizy obniżenia jakości produktu obejmowała przyporządkowanie zagrożenia do jednej z czterech kategorii: bezpieczeństwa, dyspozycyjności, wartości odżywczej lub wartości sensorycznej. Każde zagrożenie podlegało ocenie istotności zgodnie z przyjętą do tego celu trójstopniową skalą, której efektem było wyznaczenie PPO (tab. 2):

- wartość na poziomie 3 odnosi się do zagrożeń z kategorii bezpieczeństwa i powoduje eliminację produktu z możliwości przekazania go na cele społeczne (nie jest to PPO),

- wartość 2 oznacza konieczność podjęcia dodatkowej decyzji, czy bezpieczny pod względem zdrowotnym produkt może zostać przekazany na cele społeczne (może to być PPO, wymaga dalszych analiz),

- wartość na poziomie 1 oznacza, że produkt może być przekazany do organizacji charytatywnych (jest to PPO). 


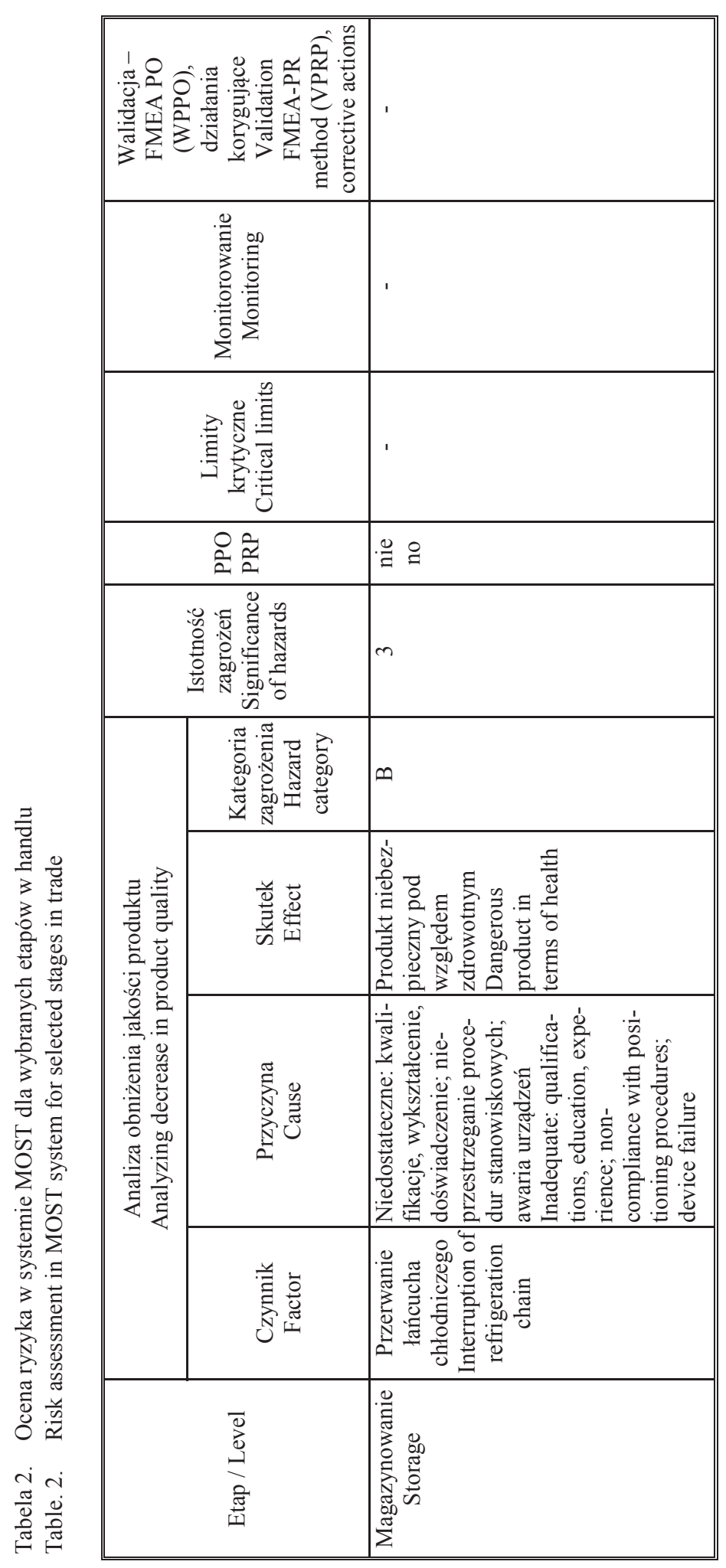




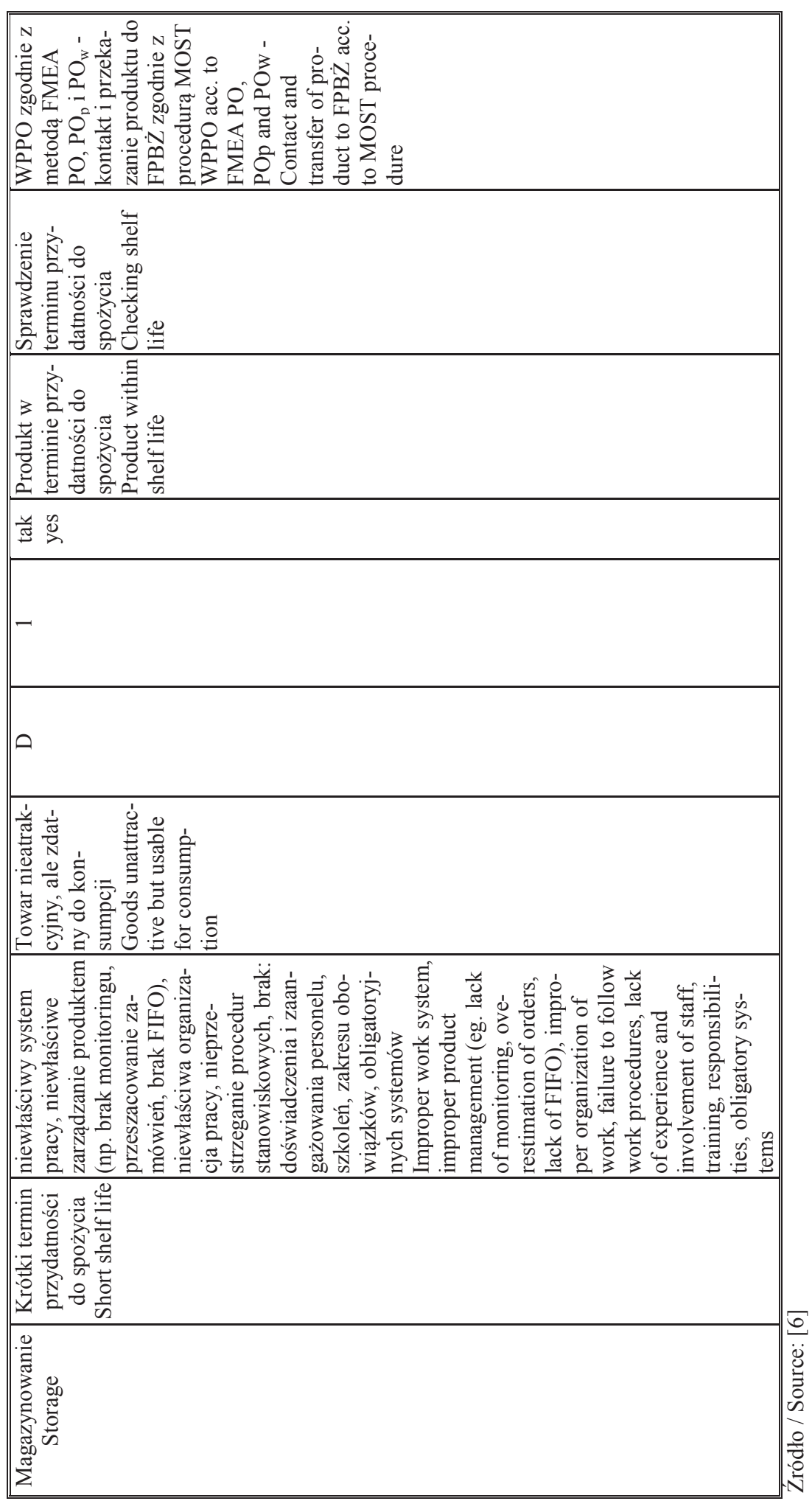




\section{Zarządzanie ryzykiem}

Określenie limitów krytycznych i działań monitorujących dla danego PPO

Kolejnym etapem wzorowanym na metodzie analizy ryzyka jest etap zarządzanie ryzykiem, w ramach którego określeniu podlegały limity krytyczne oraz działania monitorujące, umożliwiające odzysk produktu w danym PPO. Podobnie jak w obligatoryjnym systemie HACCP, za limity krytyczne umożliwiające odzysk produktu uznano kryterium oddzielające, co jest akceptowane (możliwe do odzyskania), od tego co nie jest akceptowane (niemożliwe do odzyskania). Natomiast monitorowanie zdefiniowano jako przeprowadzenie zaplanowanej sekwencji obserwacji lub pomiarów parametrów kontrolnych w celu upewnienia się, że można odzyskać produkt z danego PPO. Przykładem limitu krytycznego w przypadku magazynowania w handlu może być produkt w terminie przydatności do spożycia, natomiast monitoring obejmuje sprawdzenie terminu przydatności do spożycia (tab. 2).

Walidacja Potencjalnych Punktów Odzysku (PPO) celem potwierdzenia ostatecznych Punktów Odzysku (PO) (metoda FMEA-PO) oraz zaplanowanie dziatań korygujących w celu przekazania produktu z wyznaczonych $P O$

W ramach działań korygujących, na drodze adaptacji metody FMEA, opracowano autorską metodę FMEA-PO, która ma na celu potwierdzenie, czy dany PPO może zostać Punktem Odzysku (PO) żywności na cele społeczne (tab. 1 i 2). W ramach opracowanej metody FMEA-PO analizie poddawane są takie składowe, jak: możliwość wykrycia zagrożeń w zakładzie (A), możliwość zagospodarowania produktów przez organizacje pożytku publicznego (B) oraz zachowanie jakości produktów do momentu konsumpcji (C). Dla komponentów A, B i C ustanowiono 5-stopniową skalę punktową, w której brak możliwości wykrycia zagrożeń wynosi 1, a natychmiastowa możliwość wykrycia -5 . Po pomnożeniu ustalonych wartości $(\mathrm{A} \times \mathrm{B} \times \mathrm{C})$ otrzymuje się wynik z zakresu $1 \div 125$. W przypadku wartości $27 \div 125$ uzyskuje się potwierdzenie PO, $17 \div 26$ - warunkowy punkt odzysku, a $1 \div 16$ - odrzucony punkt odzysku [5].

Ostatnim elementem jest przekazanie żywności z wyznaczonego PO do Organizacji zajmującej się jej dalszą redystrybucją do osób potrzebujących. Zgodnie z założeniami samej procedury MOST, wszelkie podejmowane w tym zakresie czynności powinny odbywać się na mocy umowy o współpracy w zakresie nieodpłatnego przekazywania żywności pomiędzy stronami, a podjęte działania winny przebiegać zgodnie z zakresem obowiązków przedstawionym w procedurze MOST: Firma - przekazanie/odbiór - Federacja Polskich Banków Żywności (załącznik Z8-MOST-PW-1 do przewodnika wdrażania systemu MOST) [6]. 
Ocena Systemu MOST (Procedura audytu z check-lista)

W ramach zarządzania ryzykiem na etapie monitorowania i przeglądów została opracowana procedura audytu systemu MOST wraz z listą pytań kontrolnych (checklista). Opracowano również wzór karty raportu wraz z arkuszem stwierdzonych podczas audytu niezgodności, dzięki którym możliwa jest weryfikacja systemu.

Zgodnie z procedurą obowiązkiem audytowym objęte są zarówno przedsiębiorstwa przekazujące żywność na cele społeczne, jak również same organizacje zajmujące się nieodpłatnym dystrybuowaniem żywności wśród osób potrzebujących (m.in. prowadzące jadłodajnie). Natomiast częstotliwość przeprowadzania audytu całego systemu powinna być zgodna z przyjętym harmonogramem, jednak nie rzadziej niż raz w roku. Należy również zaznaczyć, że audyt powinien odbywać się każdorazowo po wystąpieniu istotnych zmian w technologii i rodzaju produkowanych wyrobów. Każdorazowo audyt należy przeprowadzać z wykorzystaniem check-listy, a jego wynik powinien stanowić raport przekazany w dalszym toku pełnomocnikowi ds. systemu MOST, który podejmuje działania korygujące.

\section{Komunikacja ryzyka}

Ostatnim elementem budującym koncepcję opracowanego modelu MOST, podobnie jak w klasycznej metodzie analizy ryzyka, jest komunikacja ryzyka pomiędzy przedsiębiorstwem przekazującym żywność, organizacjami zajmującymi się jej pozyskiwaniem i późniejszą redystrybucją oraz samymi beneficjentami pomocy żywnościowej (rys. 2). Istotne jest, aby dialog ten przebiegał w sposób zrozumiały dla każdej ze stron, dlatego też w dalszej perspektywie jako ciągłość działań nad wdrożeniem modelu MOST w wybranych przedsiębiorstwach oraz organizacjach zajmujących się redystrybucją żywności na cele społeczne należy przeprowadzić szereg szkoleń przez specjalistów z Polskiego Towarzystwa Technologów Żywności (rys. 2). Należy jednak pamiętać, że bazowym problemem, który może stanowić trudność we wdrażaniu każdego innowacyjnego rozwiązania jest brak zaangażowania kadry kierowniczej oraz zarządu. Dlatego też proces wdrażania systemu MOST powinien rozpoczynać się od szkoleń kadry najwyższego szczebla w celu zwiększenia świadomości na temat korzyści płynących z danego rozwiązania oraz uzyskanie jej pełnego wsparcia.

W dalszym ciągu, w ten nowy w Polsce projekt zarządzania stratami żywności będzie należało angażować przedsiębiorstwa i budować przyjazną formę dialogu, w którym przepływ informacji odbywa się w obu kierunkach, tj. ,z dołu” (od pracowników) oraz „z góry” (od kadry). Warto również rozważyć prowadzenie szkolenia wdrażającego procedurę MOST przez kadrę przedsiębiorstwa przy udziale i wsparciu specjalistów z tego zakresu, co może wpłynąć na eliminację wśród pracowników niższego szczebla bariery przed nieznanym i przed koniecznością wprowadzenia zmian. 


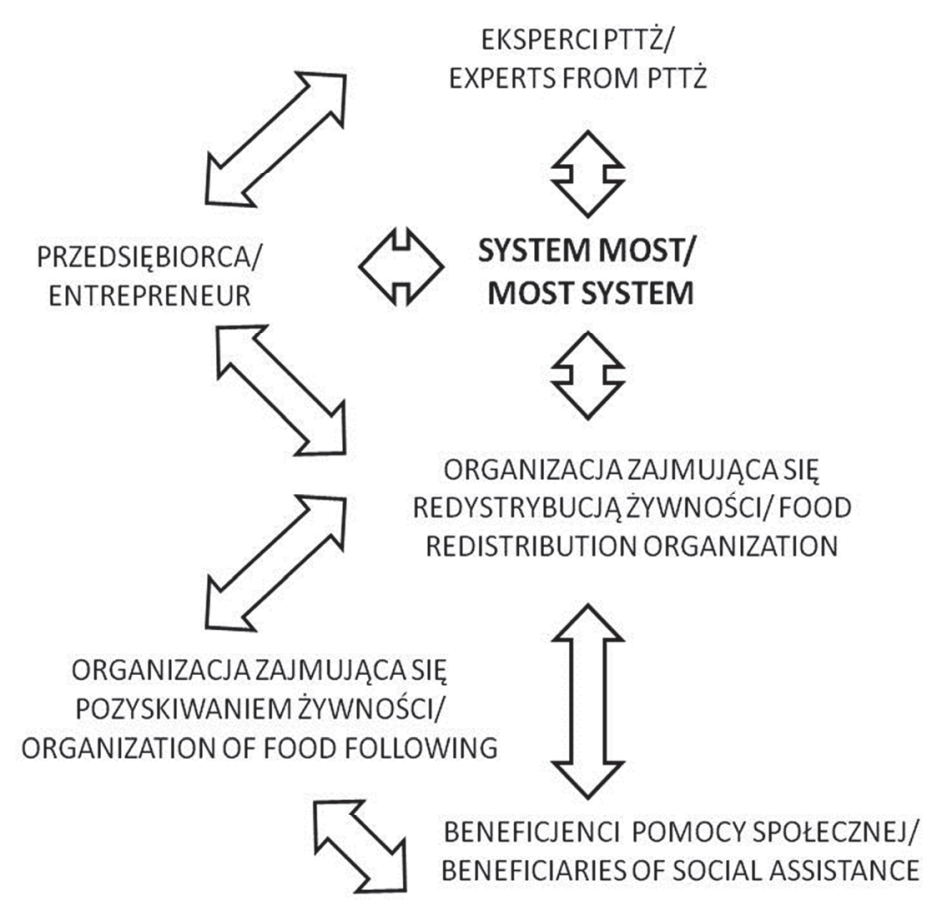

Rys. 2. Komunikacja ryzyka Systemu MOST

Fig. 2. Risk communication under MOST System

Źródło / Source: Opracowanie własne / The authors' own study

Taki model wdrażania jest zalecany ze względu na aspekt budowania wspólnej odpowiedzialności, zmian w myśleniu i zarządzaniu oraz eliminacji problemów komunikacyjnych wśród całego zespołu. Ponadto rozwój przedsiębiorstwa i otwartość na zmiany wpływa na wzrost projakościowego charakteru przedsiębiorstwa, które dba o swój rozwój oraz swoich pracowników, gdzie optymalizowane są koszty, a środowisko pracy w odczuciu pracowników staje się bezpieczniejsze i bardziej przyjazne. Dzięki temu wdrażanie kolejnych zmian może napotykać na mniejszy opór i przychodzić zdecydowanie łatwiej $[3,6]$.

\section{Podsumowanie}

W badaniach własnych nad opracowaniem systemu MOST wykorzystano dwubiegunowy charakter pojęcia „ryzyko”, które zostało zinterpretowane zarówno jako stan zagrożenia utraty żywności (w produktach lub procesach) oraz jako szansa na wcześniejsze jej pozyskanie, przekazanie na cele społeczne i ochronienie jej przed 
zmarnowaniem. Zastosowanie analogii pomiędzy znanymi elementami oraz pojęciami uniwersalnej dla wielu branż metody analizy ryzyka umożliwiło opracowanie jasnego i ustrukturyzowanego systemu wspomagającego wymianę informacji (wiedza, komunikacja) pomiędzy poszczególnymi partnerami biorącymi udział w procesach zagospodarowania niesprzedanej żywności. Dzięki powszechności zastosowania i znajomości założeń metody analizy ryzyka wdrożenie innowacyjnego modelu, jakim jest procedura MOST, będzie procesem łatwiejszym dla wszystkich zaangażowanych stron.

Reasumując, opracowany system MOST w sposób systemowy obejmuje identyfikację i ocenę ryzyka poniesienia strat żywności oraz sposoby zarządzania nimi i komunikowania pomiędzy zainteresowanymi stronami, w tym beneficjentami pomocy żywnościowej. Dzięki zastosowaniu metody analizy ryzyka, zaproponowany system może stanowić bazę do dalszych badań nad stratami kolejnych grup produktów żywnościowych, a etap komunikacji w sposób cykliczny służyć będzie do zbierania uwag mających na celu ciągłe udoskonalanie wdrożonego systemu.

\section{Literatura}

[1] Buchner B., Fishler C., Gustafson E., Reily J., Riccardi G., Ricordi C., Veronesi U.: Food waste: Causes, impacts and proposals. Barilla Center for Food and Nutrition, Rome, Italy, 2012.

[2] FAO 2011: Global food losses and food waste. Extent, causes and prevention. Study conducted for the International Congress 'Save Food' at Interpack in Düsseldorf. Germany. FAO, Rome, Italy, 2011.

[3] Gundlach M.: Praktyki 5S jako pierwszy krok do wdrożenia produkcji odchudzonej w przedsiębiorstwie produkcyjnym - rozwinięcie teorii 6S. Zesz. Nauk. Organizacja i Zarządzanie. Wyd. Politechniki Łódzkiej, 2009, 45, 19-40.

[4] Gustavsson J., Cederberg C., Sonesson U., van Otterdijk R., Meybeck A.: Global food losses and food waste: Extent, causes and prevention. FAO, Rome, Italy, 2011.

[5] Kołożyn-Krajewska D., Bilska B., Krajewski K., Wrzosek M., Trafiałek J.: Projekt MOST jako innowacyjne rozwiązanie dla zakładów produkcji i dystrybucji żywności, Innowacyjne rozwiązania w technologii żywności i żywieniu człowieka. W: Innowacyjne rozwiązania w technologii żywności i żywieniu człowieka. Red. T. Tarko, I. Drożdż, D. Najgebauer-Lejko, A. Duda-Chodak. Oddz. Małopolski PTTŻ, Kraków 2016, ss. 185-194.

[6] Kołożyn-Krajewska D., Bilska B., Wrzosek M., Krajewski K., Lipińska M., Tomaszewska M.: MOST-PW-1. Model Ograniczania Strat i Marnowania Żywności z Korzyścią dla Społeczeństwa (MOST). Przewodnik wdrażania. Red. B. Bilska, D. Kołożyn-Krajewska. Wyd. Nauk. PTTŻ, Kraków 2016.

[7] Kołożyn-Krajewska D., Sikora T.: Zarządzanie bezpieczeństwem żywności, Wyd. C.H. Beck, Warszawa 2010.

[8] Kołożyn-Krajewska D., Wrzosek M., Bilska B., Krajewski K.: Ryzyko powstawania strat i marnotrawstwa żywności a możliwość ich ograniczania. W: Technologia produkcji i bezpieczeństwo żywności. Red. T. Tarko, A. Duda-Chodak, M. Witczak, D. Najgebauer-Lejko. Oddz. Małopolski PTTŻ, Kraków 2016, ss. 5-16.

[9] Michalak J.: Refleksje nad pojęciem ryzyka. Ruch Prawniczy, Ekonomiczny i Socjologiczny, 2004, 1 (60), 119-131.

[10] Panasiewicz A.: Metodyka zarządzania ryzykiem zgodna ze standardem ISO 31000. Prace Naukowe UE we Wrocławiu, 2012, 265, 282-293.

[11] Parfitt J., Barthel M., Macnaughton S.: Food waste within food supply chains: Quantification and potential for change to 2050. Phil. Trans. R. Soc., 2010, 365, 3065-3081. 
[12] Preparatory Study on Food Waste Across EU 27. Technical Report, October 2010. [online] European Communities. Dostęp w Internecie [05.05.2017]: http://ec.europa.eu/environment/eussd/ pdf/bio_foodwaste_report.pdf

[13] Rozporządzenie Parlamentu Europejskiego nr 178/2002 z dnia 28 stycznia 2002 r. ustanawiające ogólne zasady i wymagania prawa żywnościowego, powołujące Europejski Urząd ds. Bezpieczeństwa Żywności oraz ustanawiające procedury w zakresie bezpieczeństwa żywności, Dz. U. L 179.

[14] Serafin R.: Koncepcja systemu adaptacyjnego zarządzania ryzykiem dostaw w procesach produkcyjnych. Zarządzanie Przedsiębiorstwem, 2013, 3, 46-52.

[15] Szlachcic B.: Analiza ryzyka i zarządzania ryzykiem jako element systemu zarządzania kryzysowego w organizacji. Zesz. Nauk. UPH w Siedlcach. Seria: Administracja i Zarządzanie, 2014, 30 (103), 229-241.

[16] Which types of food are wasted the most. 2012. [online] Dostęp w Internecie [05.05.2017]: http://england.lovefoodhatewaste.com/node/3420

[17] Wrzosek M., Bilska B., Kołożyn-Krajewska D., Krajewski K., Kondraszuk A.: Określenie skali i przyczyn strat żywności w handlu detalicznym na przykładzie mleka i jego przetworów. Żywność. Nauka. Technologia. Jakość, 2014, 2 (93), 225-238.

[18] Wrzosek M., Bilska B., Kołożyn-Krajewska D., Krajewski K.: Ograniczenie strat produktów mleczarskich $\mathrm{w}$ handlu detalicznym jako element społecznie odpowiedzialnego biznesu. Rocz. Nauk. Stowarzyszenia Ekonomistów Rolnictwa i Agrobiznesu, 2014, 16 (6), 541-546.

[19] Wrzosek M., Kołożyn-Krajewska D., Krajewski K.: Nieracjonalne wykorzystanie żywności - perspektywa globalna i odpowiedzialności społecznej. Prace Studentów i Młodych Pracowników Nauki. Teoria i praktyka zarządzania przedsiębiorstwem. Wybrane zagadnienia, 2012, 4, 59-72.

\section{APPLYING RISK ANALYSIS TO DEVELOP INNOVATIVE FOOD LOSS AND WASTE REDUCTION SYSTEM IN RETAIL TRADE (MOST SYSTEM)}

$$
\text { S u m m a r y }
$$

Redistributing food for social purposes can be one of the key and desirable ways to reduce food losses. This solution offers many-sided benefits; among them, the most important one is an improved access to food for low-income people. Such actions are common practices in the European countries, e.g. in the United Kingdom and in Spain, where food surpluses are donated to social organizations.

The objective of the research study was to apply a risk analysis method to develop an innovative system to reduce food loss and food waste in the retail trade (Model of Limiting Food Losses for the benefit of society - acronym: MOST), i.e. a system understood as the whole of activities and actions undertaken by the Entrepreneur in consultation with the Food Redistribution Organization. The paper presents a summary of the research studies focused on developing a system that would make it possible to identify food losses incurred in the retail trade and to manage the fit-to-be-eaten food for social purposes. The proposed MOST system was developed based on the risk analysis method that is universal for diverse industries and on the HACCP system the use of which is mandatory in food businesses; therefore, the MOST system can be incorporated into the business operations without incurring additional financial expenditures. The system developed includes procedures that appear characteristic for the risk analysis such as risk assessment, risk management, and risk communication. The identification of factors and causes of food losses was analyzed thoroughly; on the basis thereof Potential Recovery Points are determined, which, after validation, can become Recovery Points.

Key words: risk analysis, risk assessment of food losses, food losses management in retail trade, MOST system, food losses in retail trade 